\title{
Early Paleogene agglutinated foraminifera from the Middle East (Egypt and Arabia) and their distribution in the Tethys
}

\author{
Haidar Salim ANAN
}

Prof. of Stratigraphy and Micropaleontology, Gaza P.O. Box 1126, Palestine; profanan@gmail.com

Anan, H.S. 2016. Early Paleogene agglutinated foraminifera from the Middle East (Egypt and Arabia) and their distribution in the Tethys. [Foraminíferos bentónicos aglutinados del Paleógeno inferior del Oriente Medio (Egipto y Arabia) y su distribución en el Tetis]. Spanish Journal of Palaeontology, 31 (2), 353-368.

\begin{abstract}
Thirty-two small benthic foraminiferal species belonging to sixteen genera are originally described from the Paleogene rocks (mainly Paleocene and Eocene) from three countries of the Middle East: Egypt, Jordan and United Arab Emirates (UAE). Some of these species are also recorded in other localities of the Tethys, i.e. United States of America (USA), France, Hungary, Tunisia, Qatar, Yemen and Pakistan. Some of these taxa extend into younger stratigraphic horizons than the Paleogene. The palaeontology, stratigraphy, palaeoenvironment and palaeogeography of these species in the Middle East and other Tethyan localities are presented.
\end{abstract}

Keywords: Paleogene, benthic foraminifera, Middle East, Tethys.

\section{RESUMEN}

En este trabajo se describen 32 especies de foraminíferos bentónicos, pertenecientes a 16 géneros, de rocas del Paleógeno (principalmente Paleoceno y Eoceno) de tres países de Oriente Medio: Egipto, Jordania y Emiratos Árabes Unidos. Algunas de estas especies han sido reconocidas en otras localidades del Tetis, como Norte América, Francia, Hungria, Túnez, Qatar, Yemen y Pakistán. Algunos de los taxa descritos se extienden hacia épocas más recientes. Se presenta la paleontología, el rango estratigráfico, el paleoambiente y la distribución paleogeográfica de estas especies en Oriente Medio y otras localidades del Tethys.

Palabras clave: Paleógeno, foraminíferos bentónicos, Oriente Medio, Tetis. 


\section{INTRODUCTION}

The present study aims at reviewing the palaeontology and biogeography of the thirty-two Paleogene small benthic foraminifera that were originally erected by many different authors from three Middle East countries (Fig. 1): Egypt (Schwager, 1876, 1883; Nakkady, 1950, 1959; LeRoy, 1953; Said \& Kenawy, 1956; Anan, 1994, 2002, 2008b, 2012b; Luger, 1988; El-Dawy, 2001), Jordan (Futyan, 1976) and the United Arab Emirates (Anan, 2003, 2015). Many studies recorded some of these taxa

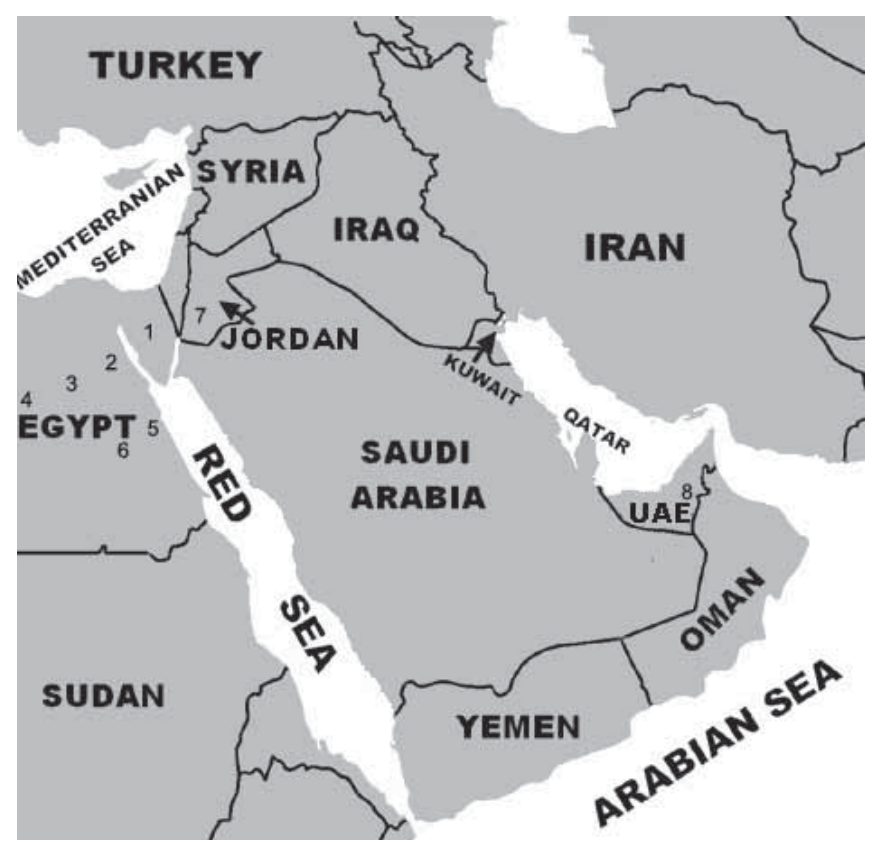

Figure 1. Map of the Middle East countries: Egypt (1. Sinai, 2. El Sheikh Fadl area, 3. Fayoum area, 4. Maqfi section, 5. Duwi section, 6. Luxor section), Jordan (7. Tell Burma section) and the United Arab Emirates, UAE (8. J. Hafit). in wider geographic areas in the Tethys than the original descriptions, from the Atlantic to Indian Oceans via the Mediterranean Sea (Fig. 2).

\section{SYSTEMATIC PALAEOTOLOGY}

The taxonomy of Kaminski (2014) is followed here. Thirty-two recorded species are illustrated in Figure 3. The stratigraphic value of these species is important for palaeobiogeographic correlations in three countries of the Middle East and other localities in the Tethys.

Class FORAMINIFEREA d'Orbigny, 1826 Subclass MONOTHALAMANA Pawlowski, Holzmann \& Tyszka, in Kaminski, 2014

Order ASTRORHIZIDA Lankester, 1885

Suborder ASTRORHIZINA Lankester, 1885

Superfamily ASTRORHIZACEA Brady, 1881

Family Rabdamminidae Brady, 1884

Subfamily Bathysiphoninae Avnimelech, 1952

Genus Bathysiphon Sars, 1872

Type species Bathysiphon filiformis Sars, 1872

Bathysiphon paleocenicus El-Dawy, 2001

(Fig. 3a)

2001 Bathysiphon paleocenicus El-Dawy, p. 42, pl. 1 , fig. 1.

2012b Bathysiphon paleocenicus Anan, p. 63, pl. 1, figs 2,3 .

2015 Bathysiphon paleocenicus Anan, p. 241, fig. 4.2.

This species was originally described from the late Paleocene of the El Sheikh Fadl area, east central Egypt

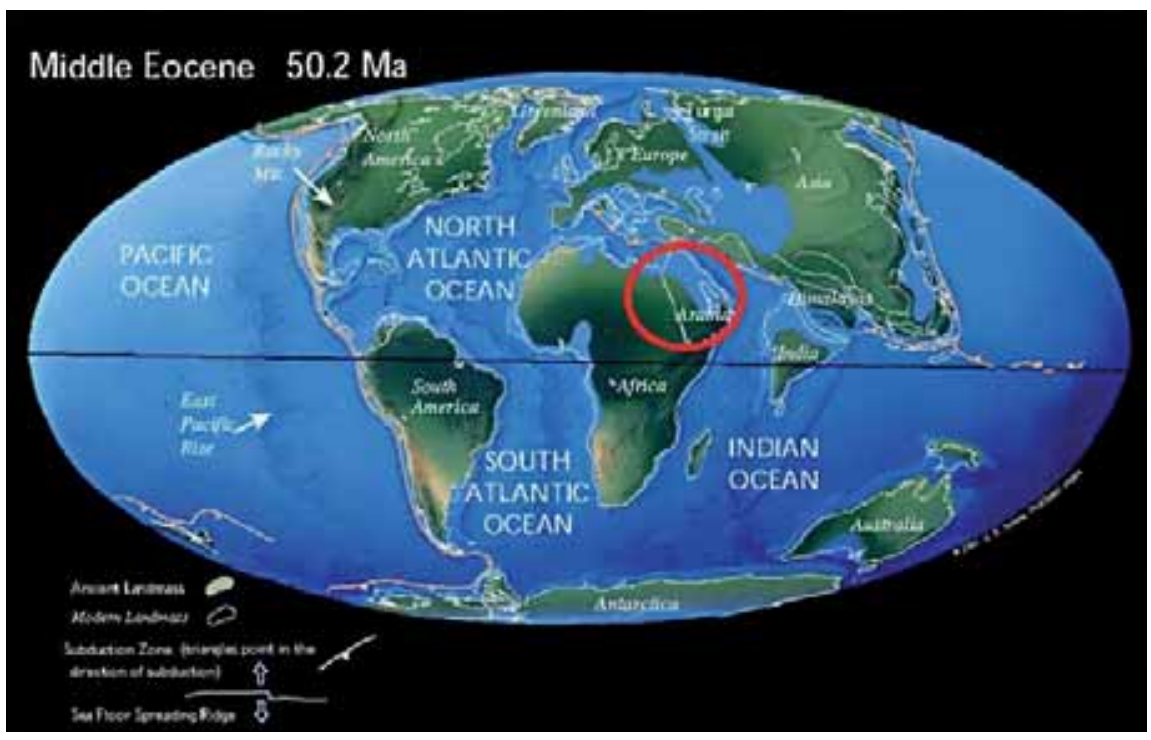

Figure 2. Paleaogeographic map during the middle Eocene including the location of the Middle East (Egypt and Arabia). After http://www. newjerseypaleo.com/fossilsbyera/ tertiary-fossils. 
(the holotype is deposited in Minia University, Geology Department, Egypt, MUGD F17 ). It was also recorded by Anan (2012b, 2015) in the Danian/Selandian transition of Jabal Mundassa (UAE), for the first time outside Egypt. An early Eocene Bathysiphon species is needed to complete the lineage from the Paleocene B. paleocenicus to the middle-late Eocene Bathysiphon saidi (Anan, 1994). The latter species was recorded from Egypt and the UAE.

Bathysiphon saidi (Anan, 1994)

(Fig. 3b)

1994 Rhabdammina saidi Anan, p. 218, fig. 8. 1.

2005a Bathysiphon saidi (Anan), Anan, p. 19, pl. 1, fig. 2.

2007 Bathysiphon saidi Ozsvárt, p. 29, pl. 1, figs 2, 3.

2007 Bathysiphon saidi Abd-Elshafy et al., p. 103.

2011 Bathysiphon saidi Boukhary et al., p. 537.

2011 Bathysiphon saidi Anan, p. 51, pl. 1, fig. 1.

The wide stratigraphic range of the Triassic-Holocene genus Bathysiphon differs from the Holocene Rhabdammina Sars (1869) by its straight unbranched elongated tube. This species has an elongated test and wall constructed of firmly cemented coarse sand grains with a rough exterior. The coarsely agglutinated Bathysiphon abbassi of Hussein (1997) and Bathysiphon sp. 1 of Abul-Nasr (2000) are closely conspecific with B. saidi (Anan, 1994). B. saidi (the holotype is deposited in Ain Shams University, Geology Department, Egypt, ASUGD A2) was originally described from the Bartonian-Priabonian of Fayoum and Sinai (Egypt), and later from the same stratigraphic horizon of Jabal Hafit (UAE) and Hungary.

Suborder HEMISPHAERAMMININA Loeblich \& Tappan, 1961, emended Mikhalevich, 1995

Family Saccamminidae Brady, 1884

Subfamily Thurammininae Miklukho-Maklay, 1963

Genus Orbulinelloides Saidova, 1975

Type species Orbulinelloides agglutinatus Saidova, 1970

\section{Orbulinelloides arabicus Anan, 2003}

(Fig. 3c)

2003 Orbulinelloides arabicus Anan, p. 531, fig. 4. 1. 2011 Orbulinelloides arabicus Anan, p. 52, pl. 1, fig. 2.

This species has a spherical-subspherical coarsely agglutinated test, apertures flush with the surface. It was originally described from the Bartonian-Priabonian of Jabal Hafit (UAE) (the holotype is deposited in the UAE University, Geology Department, UAEUGD A5). So far, it seems to be confined to the UAE.
Suborder SCHLUMBERGERININA Mikhalevich, 1980

Superfamily RZEHAKINOIDEA Cushman, 1933

Family Miliamminidae Saidova, 1981

Subfamily Miliammininae Saidova, 1981

Genus Miliammina Heron-Allen \& Earland, 1930

Type species Miliolina oblonga (Montagu) var. arenacea Chapman, 1916

Miliammina kenawyi Anan, 1994

(Fig. 3d)

1994 Miliammina kenawyi Anan, p. 218, fig. 8. 2.

2005a Miliammina kenawyi Anan, p. 19, pl. 1, fig. 3. 7.

2011 Miliammina kenawyi Anan, p. 53, pl. 1, fig. 3.

This species has a fine agglutinated smooth wall in a loose quinqueloculine arrangement with half coil chambers. M. kenawyi (the holotype is deposited in the UAE University, Geology Department, UAEUGD A3) was originally described from the Bartonian-Priabonian of Fayoum (Egypt), and later from the Bartonian of Jabal Hafit (UAE).

Family Ammomassilinidae Mikhalevich \& Kaminski, 2008

Subfamily Ammomassilininae Mikhalevich \& Kaminski, 2008

Genus Ammomassilina Cushman, 1933

Type species Massilina alveoliniformis Millett, 1898

Ammomassilina sp Anan, 1994

(Fig. 3e)

1994 Ammomassilina sp Anan, p. 219, fig. 8. 5.

2007 Ammomassilina sp Abd-Elshafy et al., p. 104.

This late Eocene species has a quinqueloculine early stage, later chambers are added on the opposite sides of the test in a single plane; wall porcelaneous with a surface layer of agglutinated fine-grains of quartz particles. It differs from the Holocene A. alveoliniformis by its finer quartz grains and older stratigraphic horizon. It is a rare species in the Guta section, Fayoum area, southwest Cairo, Egypt (the holotype is deposited in the Ain Shams University, Geology Department, Egypt, ASUGD A4). So far, it seems to be confined to Egypt.

Subfamily Ammomarginulinae Podobina, 1978

Genus Ammobaculites Cushman, 1910

Type species Spirolina agglutinans d'Orbigny, 1846

Ammobaculites coprolithiformis (Schwager, 1876)

(Fig. 3f) 
1876 Haplophragmium coprolithiformis Schwager, $\mathrm{p}$. 661, pl. 1, fig. 3 .

1949 Ammobaculites coprolithiformis Cushman, p. 2, pl. 1, fig. 9 .

1972 Ammobaculites coprolithiformis Hanzlíková, p. 46, pl. 9 , fig. 5 .

1997 Ammobaculites coprolithiformis Gebhardt, p. 22, fig. 3. 3 .

1988 Ammobaculites coprolithiformis Luger, p. 260, pl. 1, fig. 12.

2009 Ammobaculites coprolithiformis Al-Wosabi, p. 82 , pl. 1, fig. 18

This Upper Cretaceous-Paleogene species in longitudinal section shows a tightly coiled test with a planispiral coiledearly stage and a short rectilinear uncoiled adult stage. It was originally recorded from southwest Aswan (Egypt), and later from Arkansas (USA), Czech Republic, Nigeria and Yemen.

\section{Ammobaculites khargaensis Nakkady \& Talaat, in Nakkady, 1959}

(Fig. 3g)

1959 Ammobaculites khargaensis Nakkady \& Talaat, in Nakkady, p. 456, pl. 6, fig. 1.

1994 Ammobaculites khargaensis Hewaidy, p. 64, fig. 10. 3 .

2001 Ammobaculites khargaensis Hewaidy \& Strougo, p. 15, pl. 1, fig. 3 .

2003 Ammobaculites khargaensis Ali, pl. 2, figs. 1, 2. 2009 Ammobaculites khargaensis Anan, p. 33, pl. 1, fig. 1.

This Maastrichtian-early Eocene species has a strongly compressed test, subcircular early stage, comprised of about two whorls, chambers close-coiled, wall arenaceous of subangular quartz grains rather smoothly finished, aperture is a small triangular opening at the base of the last septal face of the last chamber (the holotype is deposited in the U.S. National Museum, Washington, D. C.). It seems to be confined, so far, to Egypt.

Suborder SPIROPLECTAMMININA Mikhalevich, 1992

Superfamily SPIROPLECTAMMINACEA Cushman, 1927

Family Spiroplectamminidae Cushman, 1927

Subfamily Spiroplectammininae Cushman, 1927

Genus Spiroplectinella Kisel'man, 1972

Type species Spiroplecta wrightii Silvestri, 1903

Spiroplectinella esnaensis (LeRoy, 1953)

(Fig. 3h)
1953 Spiroplectammina esnaensis LeRoy, p. 50, pl. 1, figs. 11, 12.

1976 Spiroplectinella esnaensis Aubert \& Berggren, p. 409 , pl. 1, fig. 6 .

1994 Spiroplectinella esnaensis Speijer, p. 147, pl. 3, fig. 1.

2003 Spiroplectinella esnaensis Ali, p. 124, pl. 4, figs. $16,17$.

2005 Spiroplectinella esnaensis Sztrákos, p. 184, pl. 12, fig. 16.

2007 Spiroplectinella esnaensis Alegret \& Ortiz, p. 437, pl. 1, fig. 6.

2011 Spiroplectinella esnaensis Aly et al., p. 83, pl. 1 , fig. 8.

2012 Spiroplectinella esnaensis Youssef \& Taha, pl. 1, fig. 16.

This Paleocene-early Eocene species is characterized by its raised sutures and a broad apertural face. It was originally recorded from the Paleocene of the Maqfi section (Egypt) (the holotype is deposited in the Cushman Collection No. 58024), and later from some sections in the Nile Valley, west and south Egypt, and also Tunisia and France.

Spiroplectinella paracarinata (Said \& Kenawy, 1956)

(Fig. 3i)

1956 Spiroplectammina paracarinata Said \& Kenawy, p. 122, pl. 1, fig. 13.

1996 Spiroplectammina paracarinata Anan, p. 149, fig. 3. 2.

2012b Spiroplectammina paracarinata Anan, p. 63, pl. 1, fig. 6 .

This species was originally described from the lower Eocene rocks of Sinai (Egypt) (the holotype is deposited in the U.S.N.M. P3987), and later from the early Eocene of Jabal Hafit (UAE).

Suborder VERNEUILININA Mikhalevich \& Kaminski, 2004

Superfamily VERNEUILINACEA Cushman, 1911

Family Prolixoplectidae Loeblich \& Tappan, 1985

Genus Plectina Marsson, 1878

Type species Gaudryina ruthenica Reuss, 1851

Plectina emiratensis Anan, 2003

(Fig. 3j)

2003 Plectina emiratensis Anan, p. 534, fig. 4. 2.

2011 Plectina emiratensis Anan, p. 53, pl. 1, fig. 5.

This species has short subconical test, subterminal and traverse elongate slit aperture on the apertural face 
of the last chambers and rather coarse-grained arenaceous wall. P. emiratensis (the holotype is deposited in the UAE University, Geology Department, UAE, UAEUGD A3) was originally described from the Bartonian of Jabal Hafit (UAE). So far, it seems to be confined also in the UAE.

Family Reophacellidae Mikhalevich \& Kaminski, 2004

Subfamily Verneuilininae Cushman, 1911

Genus Gaudryina d'Orbigny, 1839

Type species Gaudryina rugosa d'Orbigny, 1839

Gaudryina ameeri Anan, 2012b

(Fig. 3k)

2012b Gaudryina ameeri Anan, p. 63, pl. 1, fig. 7.

This early Eocene species has a distinctive front carinate rib, which exists along the pre-final chamber of the biserial stage, as well as the whole triserial portion. It was originally recorded from the Duwi section (Egypt) (the holotype is deposited in the Al Azhar University-Gaza, Geology Department, ASUGD A27).

Gaudryina elegantissima Said \& Kenawy, 1956 (Fig. 31)

1956 Gaudryina elegantissima Said \& Kenawy, p. 123, pl. 1, fig. 21.

1993b Gaudryina elegantissima Anan, p. 655, pl. 1, fig. 16.

1993 Gaudryina elegantissima Hewaidy \& Al-Hitmi, p. 478, pl. 4, figs. 4, 5 .

2012 Gaudryina elegantissima Ismail, p. 29, pl.1, fig. 14.

This Paleocene species has an elongated test, chambers distinct, very slightly inflated, gradually increasing in size as added, wall arenaceous smooth, aperture a semicircular opening at the base of the last chamber. It was originally recorded in Sinai (Egypt) (the holotype is deposited in the U.S.N.M. P3959), and later from the same horizon of Qarn El Barr (UAE) and Qatar.

\section{Gaudryina limbata Said \& Kenawy, 1956}

(Fig. 3m)

1956 Gaudryina limbata Said \& Kenawy, p. 123, pl. 1, fig. 23.

1993a Gaudryina limbata Anan, p. 314, pl. 1, fig. 6.

2003 Gaudryina limbata Ali, p. 120, pl. 4, fig. 4.

This Paleocene species was originally recorded from Sinai and south Egypt (the holotype is deposited in the U.S.N.M. P3961), and later from the Paleocene of Jabal Malaqet (UAE).
Gaudryina speijeri Anan, 2012

(Fig. 3n)

1994 Gaudryina cf. ellisorae Cushman, Speijer, p. 147, pl. 5, fig. 1.

2005 Gaudryina cf. ellisorae Alegret et al., p. 531.

2012b Gaudryina speijeri Anan, p. 66, pl. 1, fig. 10.

This Eearly Eocene species has very distinct carinate rib which extended from the last formed chamber of the biserial stage as well as the whole triserial portion. It differs from the Upper Cretaceous G. (Pseudogaudryina) ellisorae Cushman by its semiglobular last chamber with more circular aperture rather than a triangular last chamber with more elongated aperture as in Cushman's species. G. speijeri (the holotype from the R. Speijer's collection, 1994, sample S 738, Wadi Nukhul, Egypt) has a longer and bigger test than $G$. ameeri. Anan (2012b) explained that one edge of G. pyramidata grows to produce a carinate rib that existed along the pre-final chamber of the biserial stage and extends on the whole triserial portion on G. ameeri, while it starts in another edge from the final chamber of the biserial stage and extends along the triserial stage in G. speijeri.

\section{Gaudryina tellburmaensis Futyan, 1976}

(Fig. 3ñ)

1976 Gaudryina soldadoensis tellburmaensis Futyan, p. 521, pl. 81, figs. $1,2$.

This Paleocene-early Eocene species has an elongated test with a pyramidal triserial early portion forming about one-third of the test, followed by inflated biserial chambers semicircular in cross-section separated by deeply depressed sutures. It was recorded from the Tell Burma section, south Jordan (the holotype is deposited in the British Museum Natural History, BMNH. P49102). It seems to be confined, so far, to Jordan.

Genus Siphogaudryina Cushman, 1935

Type species Gaudryina stephensoni Cushman, 1928

Siphogaudryina africana (LeRoy, 1953)

(Fig. 3o)

1953 Gaudryina africana LeRoy, p. 30, pl. 2, figs. 7, 8 . 2000 Pseudogaudryina ? africana Sztrákos, p. 136.

2001 Gaudryina africana Hewaidy \& Strougo, p. 15, pl. 1, figs. 6, 7.

2008a Siphogaudryina africana Anan, p. 361, pl. 1, fig. 1.

This species belongs to the genus Siphogaudryina due to its subterminal apertural in the apertural face of 


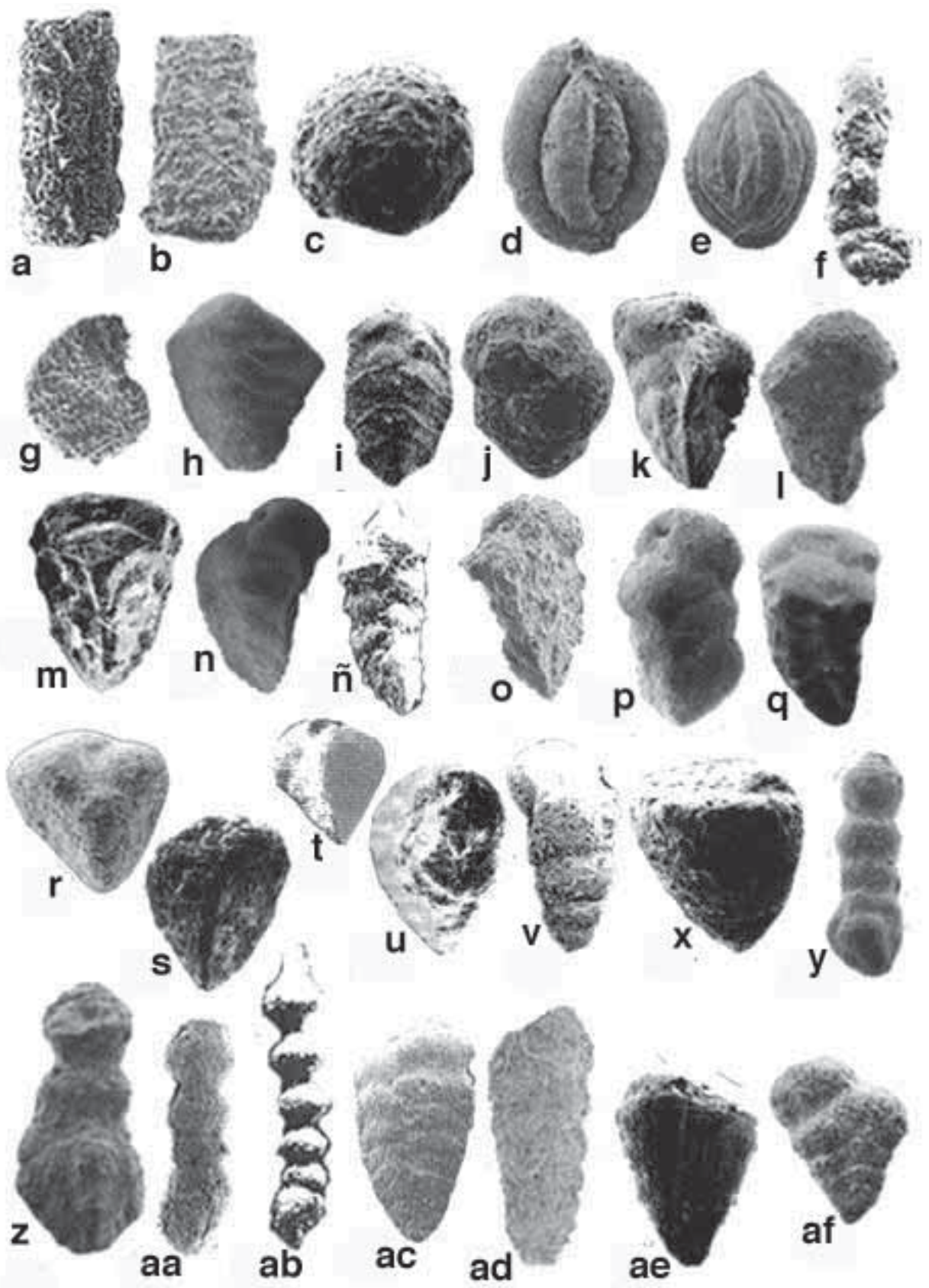

Figure 3. a) Bathysiphon paleocenicus El-Dawy, 2001 x 40; b) Bathysiphon saidi (Anan, 1994) x 20; c) Orbulinelloides arabicus Anan, 2003 x 55; d) Miliammina kenawyi Anan, 2005 x 33; e) Ammomassilina sp Anan, 1994 x 40; f) Ammobaculites coprolithiformis (Schwager, 1867; after Luger, 1988) x100; g) Ammobaculites khargaensis Nakkady \& Talaat, in Nakkady, 1959 x 20; h) Spiroplectinella esnaensis (LeRoy, 1953; after Speijer, 1994) x 45; i) Spiroplectinella paracarinata (Said \& Kenawy, 1956; after Anan, 1996) x 100; j) Plectina emiratensis Anan, 2003 x 40; k) Gaudryina ameeri Anan, 2012b x 50; l) Gaudryina elegantissima Said \& Kenawy (1956; after Anan, 1993) x 30; m) Gaudryina limbata Said \& Kenawy (1956; after Anan, 1993) x 100; n) Gaudryina speijeri Anan, 2012b x 50; ñ) Gaudryina tellburmaensis Futyan, 1976 x 40; o) Siphogaudryina africana (LeRoy, 1953; after Anan, 2008a) x 35; p) Siphogaudryina nekhlensis (Said \& Kenawy, 1956; after Speijer, 1994) x 40; q) Siphogaudryina strougoi Anan, 2002 x 15; r) Verneuilina aegyptiaca Said \& Kenawy (1956; after Anan, 2004) x 45; s) Verneuilina karreri Said \& Kenawy (1956; after Hewaidy \& Al-Hitmi, 1993) x 100; t) Verneuilina luxorensis Nakkady (1950; after Anan, 2004) x 60; u) Arenobulimina aegyptiaca Said \& Kenawy (1956; after Anan, 1993) x 55; v) Dorothia sinaensis Said \& Kenawy (1956; after Ali, 2003) x 50; x) Marssonella hafitensis Anan, 2003 x 50; y) Pseudoclavulina farafraensis LeRoy (1953; after Anan, 2005) x 50; z) Pseudoclavulina hewaidyi Anan, 2008b x 25; aa) Pseudoclavulina maqfiensis LeRoy (1953; after Ismail, 1996) x 50; ab) Clavulina barnardi Futyan, 1976 x 60; ac) Textularia fahmyi Anan, 1994 x 40; ad) Textularia farafraensis LeRoy (1953; after Aly et al., 2011) x 45; ae) Textularia nilotica (Schwager, 1883; after Hewaidy \& Al Hitmi, 1993) x 170; af) Textularia schwageri LeRoy (1953; after Anan, 2008a) x 40. 
the last-formed chamber, instead of the inner marginal aperture of the genus Gaudryina d'Orbigny. It has a large elongated robust test, tapering initial triserial portion and greatest breadth at the beginning of the biserial stage, with distinctive four longitudinal not acute edges running nearly parallel to the periphery, two out of them appear on the apertural view along the test, sutures indistinct and depressed (the holotype is deposited in the Cushman Collection No. 58006). Hewaidy \& Strougo (2001) considered the first appearance of this species in the early Eocene of the Maqfi section, Egypt and later in France.

\section{Siphogaudryina nekhlensis (Said \& Kenawy, 1956)} (Fig. 3p)

1956 Gaudryina nekhlensis Said \& Kenawy, p. 124, pl. 1, fig. 24.

1994 Gaudryina nekhlensis Speijer, p. 147, pl. 1, fig. 1. 2003 Gaudryina nekhlensis Ali, p. 120, pl. 4, fig. 6. 2012a Siphogaudryina nekhlensis Anan, p. 20, pl. 1, fig. 4.

This species belongs to the genus Siphogaudryina due to its subterminal apertural face of the last-formed chamber, instead of the inner marginal aperture of the genus Gaudryina. It has large elongated robust test, tapering initial triserial portion and greatest breadth at the beginning of the biserial stage, with distinctive four longitudinal not acute edges running nearly parallel to the periphery and two out of them appearing on the apertural view along the test, sutures indistinct and depressed. This species (the holotype is deposited in the U.S.N.M. P3962) was originally recorded in the Paleocene of the Nekhl section and south Egypt. So far, it seems to be confined to Egypt.

\section{Siphogaudryina strougoi Anan, 2002}

(Fig. 3q)

2002 Siphogaudryina strougoi Anan, p. 141, fig. 2. 1.

This Paleocene species has an elongated large test with a smoothly finished arenaceous wall, tapering early stage, triserial and triangular in cross section, later reaching biserial greatest width a near the apertural end with nearly quadrangular section. It is distinguished by distinctive five longitudinal ridges running nearly parallel to the periphery and three of them appear on the apertural view along the test, sutures raised and transverse, subterminal apertural face of the last-formed chamber. S. strougoi (the holotype is deposited in the Ain Shams University, Geology Department, Egypt, ASUGD A15) was originally described from the Thanetian of Wadi Ed Dakhl (Egypt). Anan (2010) considered it an excellent marker species for the Paleocene-Eocene boundary in Egypt.
Genus Verneuilina d'Orbigny, 1839

Type species Verneuilina tricarinata d'Orbigny, 1839

Verneuilina aegyptiaca Said \& Kenawy, 1956

(Fig. 3r)

1956 Verneuilina aegyptiaca Said \& Kenawy, p. 122, pl. 1, fig. 16.

1970 Verneuilina aegyptiaca Al-Omari, p. 49.

1993b Verneuilina aegyptiaca Anan, p. 656, pl. 2, fig. 2.

2004 Verneuilina aegyptiaca Anan, p. 41, pl. 1, fig. 1.

2012a Verneuilina aegyptiaca Anan, p. 21, pl. 1, fig. 5.

2015 Verneuilina aegyptiaca Anan, p. 41.

This species was originally recorded in the Maastrichtian-Paleocene of Sinai, Egypt (the holotype is deposited in the U.S.N.M. P3954), and later from the Qarn El Barr (UAE) and Jabal Mundassa sections (UAE) and Iraq. Anan (2004) considered V. aegyptiaca as the precursor of the Early Eocene $V$. luxorensis (Nakkady) in the $V$. aegyptiaca - V. luxorensis lineage. Anan (2010) considered it an excellent marker species of the PaleoceneEocene boundary in Egypt.

\section{Verneuilina karreri Said \& Kenawy, 1956}

(Fig. 3s)

1956 Verneuilina karreri Said \& Kenawy, p. 122, pl. 1, fig. 17.

1970 Valvoreussella karreri Al-Omari, p. 49.

1993 Valvoreussella karreri Hewaidy \& Al-Hitmi, p. 481, pl. 6, figs.7, 8 .

2005b Verneuilina karreri Anan, p. 82, pl. 1, fig. 5.

2012a Verneuilina karreri Anan, p. 21, pl. 1, fig. 6.

This species was recorded from the MaastrichtianPaleocene of Sinai, Egypt (the holotype is deposited in the U.S.N.M. P3955), and later from Wadi Ed Dakhl, west Gulf of Suez (Egypt), and Iraq. It occurs in Maastrichtianearly Eocene of Qatar.

\section{Verneuilina luxorensis Nakkady, 1950}

(Fig. 3t)

1950 Verneuilina luxorensis Nakkady, p. 683, pl. 89, figs. 6,7 .

2004 Verneuilina luxorensis Anan, p. 42, pl. 1, fig. 2.

This early Eocene species has a pyramidal triserial test, compressed and much excavated on the three lateral faces, edges thin, chambers long and narrow, septal faces in the form of isosceles triangles, wall with much cement and a smoothly finished surface. $V$. luxorensis differs from the Maastrichtian-Paleocene $V$. aegyptiaca by its pyramidal test, which is more compressed and much excavated on 
three lateral thin edges. $V$. luxorensis (the holotype is deposited in the British Museum, Natural History) was originally recorded from the early Eocene of the Luxor section (Egypt). Anan (2010) considered it an excellent marker species to recognize the early Eocene in Egypt.

Suborder ATAXOPHRAGMIINA Fursenko, 1958

Superfamily Ataxophragmiacea Schwager, 1877

Family Ataxophragmiidae Schwager, 1877

Subfamily Ataxophragmiinae Schwager, 1877

Genus Arenobulimina Cushman, 1927

Type species Bulimina preslii Reuss, 1845

Arenobulimina aegyptiaca Said \& Kenawy, 1956

(Fig. 3u)

1956 Arenobulimina aegyptiaca Said \& Kenawy, p. 126, pl. 1, fig. 42.

1993a Arenobulimina aegyptiaca Anan, p. 314, pl. 1, fig. 9 .

This Paleocene species has an arenaceous wall with much cement and a smooth, conical test, slightly rounded and gradually tapering at the base, greatest breadth at the apertural end, last-formed whorl making up somewhat less than one-half of the entire surface of the test, aperture a narrow loop-shaped opening at the base of the apertural face. It was originally recorded from Sinai, Egypt (the holotype is deposited in the U.S.N.M. P3982), and later from the Paleocene of Jabal Malaqet (UAE).

Suborder TEXTULARIINA Delage \& Herouard, 1896

Superfamily Eggerellacea Cushman, 1937

Family Eggerellidae Cushman, 1937

Subfamily Dorothiinae Balakhmatova, 1972

Genus Dorothia Plummer, 1931

Type species Dorothia bulletta Carsey, 1926

\section{Dorothia sinaensis Said \& Kenawy, 1956}

(Fig. 3v)

1956 Dorothia sinaensis Said \& Kenawy, p. 128, pl. 2 , fig. 1.

2003 Dorothia sinaensis Ali, p. 120, pl. 3, fig. 22.

This late Paleocene-early Eocene species is recognized by its elongated test and large number of inflated chambers. It was recorded from Sinai (the holotype is deposited in the U.S.N.M. P3995), and south Egypt.

Genus Marssonella Cushman, 1933

Type species Gaudryina oxycona Reuss, 1860

Marssonella hafitensis Anan, 2003

(Fig. 3x)
2003 Marssonella hafitensis Anan, p. 535, fig. 4. 3.

2005a Marssonella hafitensis Anan, p. 21.

This Eocene species has conical test, nearly equal in length and width, with a subrounded early trochospiral stage, followed by a biserial stage of gradually increasing diameter, wall agglutinated of coarse grained material, terminal face concave, aperture a low basal arch on the final chamber. This species is similar to the Upper Cretaceous-Paleocene $M$. oxycona, but it differs by its more regular test, nearly equal length and width, coarsergrained wall and concave terminal face. M. hafitensis (the holotype is deposited in the UAE University, Geology Department, UAE, UAEGD A4) was originally described from the Bartonian-Priabonian of Jabal Hafit. It seems to be confined, so far, to the UAE.

Subfamily Pseudogaudryinae Loeblich \& Tappan, 1985

Genus Pseudoclavulina Cushman, 1936

Type species Clavulina clavata Cushman, 1926

\section{Pseudoclavulina farafraensis LeRoy, 1953}

(Fig. 3y)

1953 Pseudoclavulina farafraensis LeRoy, p. 44, pl. 2, fig. 9.

1993a Tritaxia farafraensis Anan, p. 314, pl. 1, fig.7.

1993 Tritaxia farafraensis Hewaidy \& Al-Hitmi, p. 481, pl. 6, figs. 5, 6 .

1995 Tritaxia farafraensis Nomura \& Brohi, p. 227, pl. 1, fig. 19.

2005b Pseudoclavulina farafraensis Anan, p. 87, pl. 1, fig. 10.

2012 Pseudoclavulina farafraensis Ismail, p. 30, pl. 1, fig. 16.

2015 Pseudoclavulina farafraensis Anan, p. 43, fig. 4.20.

The early triserial stage in Tritaxia Reuss is acute triangular and the uniserial stage is angular, whereas Pseudoclavulina Cushman differs in possessing a long cylindrical uniserial stage and subacute angles in the triserial stage. Pseudoclavulina farafraensis (the holotype is deposited in the Cushman Collection No. 58128) was recorded from the Paleocene of Egypt, and later from the UAE, Qatar and Pakistan.

\section{Pseudoclavulina hewaidyi Anan, 2008}

(Fig. 3z)

2008b Pseudoclavulina hewaidyi Anan, p. 4, pl. 1, fig. 1. 2015 Pseudoclavulina hewaidyi Anan, p. 249, fig. 4.21.

This species has distinctly large test, triserial stage triangular in cross section, discoidal chambers in the uniserial stage, which are circular in top view, wall finely arenaceous, 
sutures strongly depressed in the uniserial stage with a terminal aperture. P. hewaidyi (the holotype is deposited in the Al Azhar University-Gaza, Geology Department, ASUGD A20) was originally described from the Danian of Abu Zenima, Sinai (Egypt), and later from the UAE.

\section{Pseudoclavulina maqfiensis LeRoy, 1953}

(Fig. 3aa)

1953 Pseudoclavulina maqfiensis LeRoy, p. 44, pl. 2, figs. 16, 17.

1956 Pseudoclavulina maqfiensis Said \& Kenawy, p.125, pl. 1, fig. 31.

1996 Pseudoclavulina maqfiensis Ismail, p. 203, fig. 5. 6 .

This early Eocene species has a small test, with the earliest portion conspicuously triserial and triangular in cross-section, followed by an uniserial rounded and strongly inflated portion, wall finely arenaceous and smoothly finished. This species differs from $P$. farafraensis LeRoy by being consistently much smaller. It was originally recorded from the Maqfi section (the holotype is deposited in the Cushman Collection No. 58022), and later from Sinai and northeast Egypt.

Family Valvulinidae Berthelin, 1880

Subfamily Valvulininae Berthelin, 1880

Genus Clavulina d'Orbigny, 1826

Type species Clavulina parisiensis d'Orbigny, 1826

\section{Clavulina barnardi Futyan, 1976}

(Fig. 3ab)

1976 Clavulina barnardi Futyan, p. 522, pl. 81, figs. 3, 4 .

This Paleocene species has an elongated slender test, early portion triserial with a sharply acute apical end comprising about one-fifth to one-half of the entire test, the uniserial portion consists of three to eight flask-shaped inflated chambers with deeply excavated sutures, wall finely arenaceous with a rough surface. It was originally recorded from the Tell Burma section, south Jordan (the holotype is deposited in the British Museum Natural History, BMNH. P49101).

Superfamily Textularioidea Ehrenberg, 1838

Family Textulariidae Ehrenberg, 1838

Subfamily Textulariinae Ehrenberg, 1838

Genus Textularia Defrance, 1824

Type species Textularia sagittula Defrance, 1824
1994 Textularia fahmyi Anan, p. 218, fig. 8. 3.

2002 Textularia fahmyi Helal, p. 107, pl. 1, fig. 3.

2007 Textularia fahmyi Abd-Elshafy et al., p. 103.

2011 Textularia fahmyi Boukhary et al., p. 537.

This middle-late Eocene species has a large biserial test, $1 \frac{1}{4}$ times as long as broad, tapering toward the initial end, greatest breadth at the end chambers, and rhomboid in cross section, acute periphery, chambers about 8-10 pairs, increasing gradually in size as added, sutures depressed, wall arenaceous, consists of fine sand grains, occasionally rose colored. It was recorded from the Fayoum area (the holotype is deposited in the Ain Shams University, Geology Department, Egypt, ASUGD A4), Sinai and Nile Valley. So far, it seems to be confined to Egypt.

\section{Textularia farafraensis LeRoy, 1953}

(Fig. 3ad)

1953 Textularia farafraensis LeRoy, p. 51, pl. 2, figs 3,4 .

1956 Textularia farafraensis Said \& Kenawy, p. 122, pl, 1, fig. 14.

2011 Textularia farafraensis Aly et al., p. 84, pl. 1, fig. 12 .

2012 Textularia farafraensis Youssef \& Taha, pl. 1, fig. 4 .

This Paleocene-early Eocene species has an arenaceous wall that is rather coarse-textured, with a test about twice as long as broad. It was recorded from the Maqfi section (the holotype is deposited in the Cushman Collection No. 58069), Sinai and Nile Valley (Egypt). So far, it seems to be confined to Egypt.

\section{Textularia nilotica (Schwager, 1883)}

(Fig. 3ae)

1883 Plecanium niloticum Schwager, p. 115, pl. 26, fig. 14.

1953 Textularia nilotica LeRoy, p. 52, pl. 2, figs 1, 2.

1956 Textularia sp. Haque, p. 54, pl. 32, fig. 2.

1993 Textularia nilotica Hewaidy \& Al-Hitmi, p. 480, pl. 5, fig. 12.

2011 Textularia nilotica Aly et al., p. 85, pl. 1, fig. 13.

This early Eocene species has an elongated test, elliptical in apertural view, broadening moderately toward the apertural end, peripheral margin rounded, wall moderately rough. It was recorded from Farafra Oasis (Egypt), and later in the Nile Valley, as well as in Qatar. It seems that Haque's species is closely related to T. nilotica. 
1953 Textularia schwageri LeRoy, p. 51, pl. 2, figs 5, 6. 2003 Textularia schwageri Ali, p. 124, pl. 3, fig. 17. 2008a Textularia schwageri Anan, pl. 1, fig. 2. 2012 Textularia schwageri Youssef \& Taha, pl. 1, fig. 5.

This late Paleocene-early Eocene species has a medium test, maximum width near the apertural end, periphery rounded, wall moderately smooth. It was recorded from the Maqfi section (the holotype is deposited in the Cushman Collection No. 58072), and later from central and south Egypt. So far, it seems to be confined to Egypt.

\section{PALAEOGEOGRAPHY}

Paleogene palaeogeographic maps (Philips, 1971; Adams et al., 1983; Berggren, 1978; Zachos et al., 1993; Rosenbaum et al., 2002) show that the Tethyan Realm had been connected with the Indo-Pacific Ocean to the east and with the Atlantic Ocean to the west via the Mediterranean Sea cross the Middle East region during the Late Cretaceous and early Cenozoic times (Fig. 2). It is proved by the existence of the identified taxa from the Middle East of other localities in the Tethys. On the other hand, some authors (Moore et al., 1978; Zachos et al., 1993) recorded the extended realms of the Tethys, Indo-Pacific with Atlantic Oceans in the Maastrichtian-late Eocene. Haq \& Aubry (1978) noted that the North Africa and the Middle East formed important parts of the Tethyan link between the Atlantic and Pacific Oceans during the aarly Paleogene, particularly middle Eocene (Fig. 2). Anan (1993a) noted that the Paleocene benthic foraminifera assemblages have a close resemblance between Egypt and UAE, which show the same palaeogeographic province, and belong to the Midway-Type Fauna (about 50-200 m water depth). Haynes \& Nwabufo-Ene (1998) suggested wider Tethyan connections, as far distance as the Carpathian region and Pakistan.

Accordingly, the following remarks can be presented (Table 1). Most of the identified Paleogene species from the Middle East were described from Egypt (27/32, about $84 \%$ ), while 3 species from the UAE (about 0.09) and only two species from Jordan (about $0.06 \%$ ). Fourteen of the identified species (14/32, about $43.0 \%$ ), so far, are endemic to Egypt: Ammobaculites khargaensis, A. schwageri, Gaudryina ameeri, G. speijeri, Siphogaudryina africana, S. nekhlensis, S. strougoi, Verneuilina luxorensis, Dorothia sinaensis, Pseudoclavulina hewaidyi, P. maqfiensis, Textularia fahmyi, T. farafraensis, T. schwageri. Four of these species $(4 / 32,12.0 \%)$, so far, are endemic to the UAE: Orbulinelloides arabicus, Ammomassilina sp., Plectina emiratensis, and Marssonella hafitensis. Two of these species $(2 / 32,6.0 \%)$, so far, are endemic to Jordan: Gaudryina tellburmaensis and Clavulina barnardi.
Table 1. Palaeogeographic distribution of the Paleogene benthic foraminiferal taxa in the different Tethyan localities: $\mathbf{1 .}$ United State of America (USA), 2. France, 3. Hungary, 4. Tunisia, 5. Egypt, 6. Jordan, 7. United Arab Emirates (UAE), 8. Qatar, 9. Yemen, 10. Pakistan.

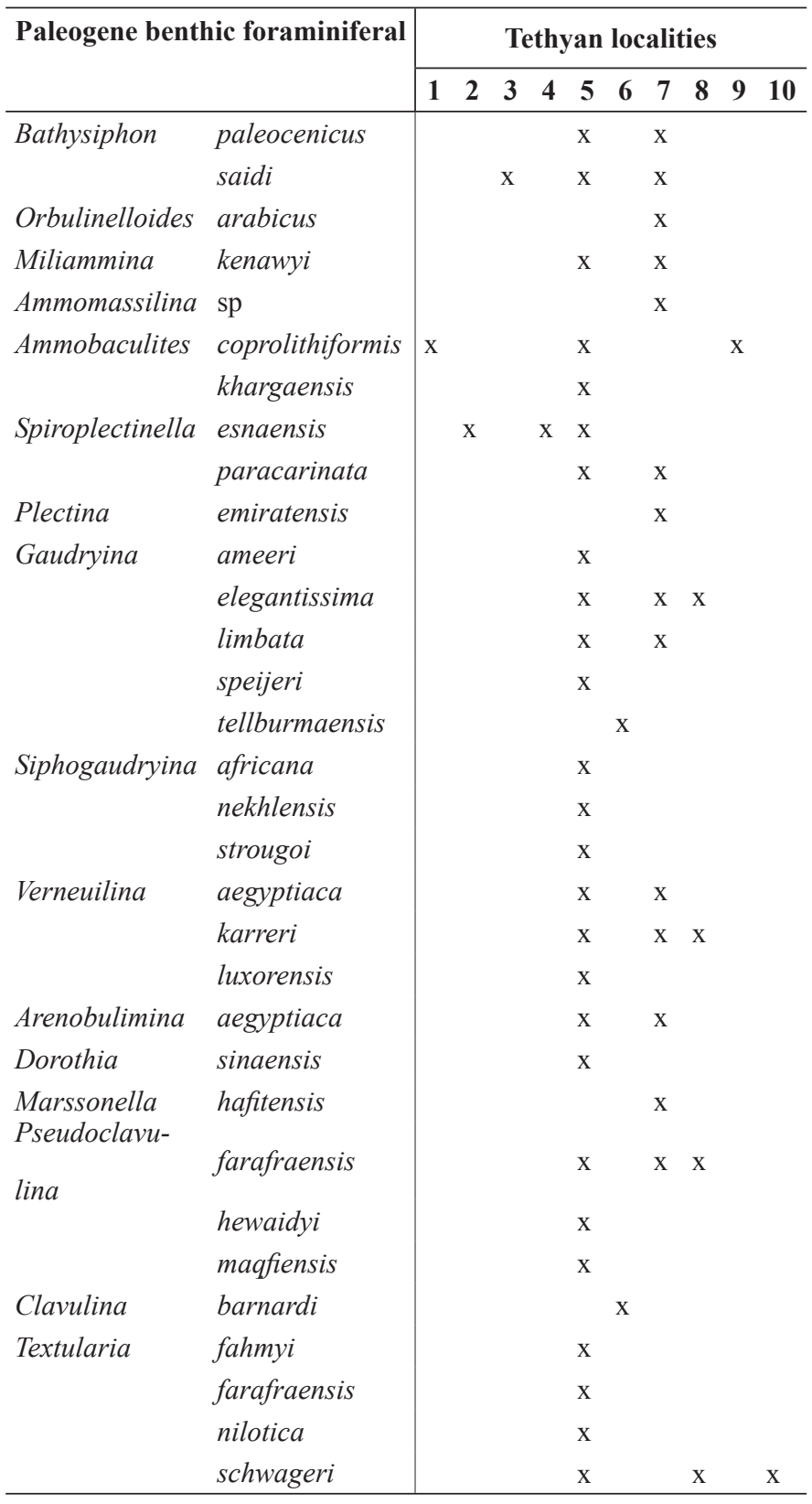

Eleven of these species (11/32, about $34 \%$ ) are recorded in both Egypt and UAE: Bathysiphon paleocenicus, $B$. saidi, Miliammina kenawyi, Ammobaculites schwageri, Spiroplectinella paracarinata, Gaudryina limbata, G. elegantissima, Verneuilina aegyptiaca, V. karreri, Pseudoclavulina farafraensis, and Arenobulimina aegyptiaca. Three of these species (3/32, about $6 \%$ ) are also endemic to Qatar.

Spiroplectinella hamdani (one of the two recorded UAE species) is recorded in Egypt (Anan, 2005), while 
the Jordanian Gyroidinoides tellburmaensis (one of three Jordanian species) is recorded outside Jordan in Tunisia (Speijer, 1994; Culver, 2003; Widmark \& Speijer, 1997), Atlantic Ocean and Spain (Widmark \& Speijer, 1997). Four Middle East species are recorded in Spain (Spiroplectinella knebeli, Eouvigerina aegyptiaca, Cibicidoides pseudoacutus, and Gyroidinoides tellburmaensis) and in Tunisia (S. knebeli, E. aegyptiaca, G. Tellburmaensis, and Cibicidoides abudurbensis), but only 3 species in Atlantic Ocean (E. aegyptiaca, C. pseudoacutus, and $G$. tellburmaensis) and also 3 in Pakistan (Tritaxia barakai, Pseudoclavulina farafraensis, and Eponides mariei), 2 species in France (C. abudurbensis, and C. pseudoacutus) and also in the Negev (Verneuilina aegyptiaca, and $C$. abudurbensis), but only E. aegyptiaca from Indian Ocean.

As explained in the palaeogeographic map (Fig. 2), the distribution of the identified Maastrichtian species from the Middle East and surrounding area in the Tethys represent tropical-subtropical faunas.

\section{PAlaEOECOLOGY}

Cushman (1949) regarded Ammobaculites coprolithiformis as a facies-index fossil for brackish littoral conditions in warm climates with high rainfall and high runoff. Cherif \& El Deeb (1984) noted that arid climate at the close of the middle Eocene became markedly wetter and seems to have been accompanied by a cooling of the water temperature. Moreover, the climatic changes inferred from the Jabal Hafit area (UAE) seems to have been widespread, at least in part of the Middle East. Anan (1995) noted that in the late Eocene time in the UAE and surrounding areas had been located in the tropical and warm-temperate region based on many faunal environmental elements. This interpretation is in accordance with the worldwide conclusions of Berggren (1978) and Moore et al. (1978).

\section{CONCLUSIONS}

The palaeontology, stratigraphy and palaeogeographic remarks are presented for 32 diagnostic agglutinated foraminiferal species described from the Paleogene rocks from Egypt, Jordan and the United Arab Emirates in the Middle East. The analysis of the Paleogene foraminiferal species of the study area in the Middle East led to the following conclusions:

1. Most of these identified species were erected from Egypt (27/32, about $84.00 \%$ ), and 9/27 of Egyptian species are erected by Said \& Kenawy (1956), 8/27 after Anan (1994, 2002, 2008a, 2008b, 2012b), 7/27 after
LeRoy (1953), 2/27 after Nakkady (1950, 1959), 2/27 after Schwager (1867, 1883), 1/27 after El-Dawy (2001).

2. Three of 32 species (about $9.00 \%$ ) from UAE were erected by Anan (2003).

3. Only two of 32 species (about $6.00 \%$ ) from Jordan were erected by Futyan (1976).

4. Cherif \& El Deeb (1984) and Anan (1995) noted that the distribution of the identified Paleogene species from the Middle East represent tropical-subtropical fauna.

5. The unclosed recorded number of Paleogene agglutinated species in different localities in the Middle East may due to the lack of detailed study for these localities, different latitudes, land barriers and/or different palaeoenvironmental conditions (depth, dissolved oxygen, salinity and temperature).

\section{ACKNOWLEDGEMENT}

Gratitude is expressed to Prof. Hanspeter Luterbacher, Tübingen University (Germany) for his kind help in photography some of the fauna. Thanks are extended to my daughter Dr. Huda Anan for her help in the development of the figures. My sincere appreciation to Prof. Abiraman Govindan (Asian Biostratigraphic Service, India) and also to Prof. Michael Kaminski (King Fahd University of Petroleum and Minerals, Saudi Arabia) for greatly improving the English language of the manuscript and valuable comments.

\section{REFERENCES}

Abd-Elshafy, E., El-Fawal, F.M., Nassif, M.S. \& Mattar, Y.E. 2007. Foraminiferal biostratigraphy of the Eocene exposures between Wadi Bagha and Wadi Matulla, west Central Sinai, Egypt. Proceeding of the 8th Conference on the Geology of Sinai for Development, Ismailia, 91-125.

Abul-Nasr, R.A. 2000. Middle-Upper Eocene benthic foraminifera of Wadi Tayiba and Wadi Bagha (western Sinai): A comparative study. Middle East Research Center, Ain Shams University, Earth Science Series, 14, 49-76.

Adams, C.G., Gentry, A.W. \& Whybrow, P.J. 1983. Dating the terminal Tethys event. Utrecht Micropaleontological Bulletin, 30, 273-298.

Ali, M.Y. 2003. Micropaleontological and stratigraphical analyses of the Late Cretaceous/Early Tertiary succession of the southern Nile Valley (Egypt). Der Fakultät für Geowissenschaften an der Ruhr-Universität Bochum vorgelegte Dissertation zur Erlangung des Grades eines, 1-197.

Alegret, L. \& Ortiz, S. 2007. Global extinction event in benthic foraminifera across the Paleocene/Eocene boundary at the 
Dababiya Stratotype section. Micropaleontology, 52, 433-447.

Alegret, L., Ortiz, S., Arenillas, I. \& Molina, E. 2005. Paleoenvironmental turnover across the Paleocene/Eocene boundary at the Stratotype section in Dababiya (Egypt) based on benthic foraminifera. Terra Nova, 17, 526-536.

Al-Omari, F.S. 1970. Upper Cretaceous and lower Cenozoic foraminifera of three oil wells in northwestern Iraq. Ph.D. Missouri University of Science and Technology, 2207, $213 \mathrm{p}$.

Al-Wosabi, M.A. 2009. Foraminiferal fauna of the Amran Group, Jabal Al-Balaq, Marib Governorate, Republic of Yemen. Egyptian Journal of Paleontology, 9, 75-103.

Aly, H.A., Abd El-Aziz, S.M. \& Abd El-Gaied, I.M. 2011. Middle and Upper Eocene benthic foraminifera from Wadi Bayad El Arab-Gebel Homret Shaibon area, Northeastern Beni Suef, Nile Valley, Egypt. Egyptian Journal of Paleontology, 11, 79-131.

Anan, H.S. 1993a. Paleocene benthonic foraminifera of Jabal Malaqet, Al Ain region, United Arab Emirates. Al-Azhar Bulletin of Science, 4, 293-320.

Anan, H.S. 1993b. Maastrichtian-Paleocene micropaleontology and biostratigraphy of Qarn El Barr section, Al Dhayd area, United Arab Emirates. Al-Azhar Bulletin of Science, 4, 639-670.

Anan, H.S. 1994. Benthic foraminifera around Middle/Upper Eocene boundary in Egypt. Middle East Research Center, Ain Shams University, Earth Science Series, 8, 210-233.

Anan, H.S. 1995. Late Eocene biostratigraphy of Jabals Malaqet and Mundassa of Al Ain region, United Arab Emirates. Revue de Micropaléontologie, 38, 3-14.

Anan, H.S. 1996. Early Eocene foraminifera of Jabal Hafit, United Arab Emirates. Middle East Research Center, Ain Shams University, Earth Science Series, 10, 147-162.

Anan, H.S. 2002. Two new benthic foraminiferal species from the Maastrichtian and Paleocene rocks of northern Egypt. Middle East Research Center, Ain Shams University, Earth Science Series, 16, 141-144.

Anan, H.S. 2003. Three new species of benthic foraminifera from the Middle-Upper Eocene of Jabal Hafit, Al Ain area, United Arab Emirates. Neues Jahrbuch für Geologie und Paläontologie, Mh., 9, 529-536.

Anan, H.S. 2004. A lineage phylogeny for some Maastrichtian to Ypresian benthic foraminifera in Egypt. Egyptian Journal of Paleontology, 4, 39-57.

Anan, H.S. 2005a, Agglutinated Middle-Upper Eocene foraminifera in Jabal Hafit, Al Ain Area, United Arab Emirates. Revue de Paléobiologie, 24, 17-27.

Anan, H.S. 2005b. Maastrichtian agglutinated foraminifera in Egypt and other Tethyan countries. Egyptian Journal of Paleontology, 5, 75-92.

Anan, H.S. 2008a. Maastrichtian-Paleogene LeRoy's benthic foraminiferal species from Egypt and Tethyan-Atlantic regions. Revue de Paléobiologie, 27, 357-376.

Anan, H.S. 2008b. Latest Maastrichtian Plummerita haggagae and Paleocene Pseudoclavulina hewaidyi, two new foraminiferal species from Egypt. Egyptian Journal of Paleontology, 8, 245-254.
Anan, H.S. 2009. Paleontology, paleogeography, paleoenvironment and stratigraphical implications of the Nakkady's benthic foraminiferal fauna in Egypt and Tethys. Egyptian Journal of Paleontology, 9, 31-52.

Anan, H.S. 2010. Contribution to the Egyptian benthic foraminifera around the Paleocene/Eocene boundary in Egypt. Egyptian Journal of Paleontology, 10, 25-47.

Anan, H.S. 2011. Paleontology, paleoenvironments, palaeogeography and stratigraphic value of the Maastrichtian-Paleogene and Recent foraminiferal species of Anan in the Middle East. Egyptian Journal of Paleontology, 11, 49-78.

Anan, H.S. 2012a. Paleontology, paleoenvironment and stratigraphic value of the Maastrichtian-Paleogene benthic foraminifera of Said \& Kenawy (1956) from Egypt and Tethys. Egyptian Journal of Paleontology, 12, 17-30.

Anan, H.S. 2012b. A lineage phylogeny from some Cretaceous-Tertiary agglutinated benthic foraminiferal species in Egypt and Tethys. Egyptian Journal of Paleontology, 12, 59-72.

Anan, H.S. 2015. Paleocene agglutinated foraminifera from Jabal Mundassa, Al Ain area, United Arab Emirates. Spanish Journal of Palaeontology, 30, 239-256.

Aubert, J. \& Berggren, W.A. 1976. Paleocene benthonic foraminiferal biostratigraphy and paleoecology of Tunisia. Bulletin du Centre de Recherches Pau- SNPA, 10, 379- 469.

Avnimelech, M. 1952. Revision of the tubular Monothalamia. Contributions from the Cushman Foundation for Foraminiferal Research, 3, 60-68.

Balakhmatova, V.T. 1972. K sistematike semeystva Ataxophragmiidae Schwager, 1877. Voprosy Mikropaleontologii, 15, 70-74.

Berggren, W.A. 1978. Recent advances in Cenozoic planktonic foraminiferal biostratigraphy, biochronology, and biogeography: Atlantic Ocean. Micropaleontology, 24, 337-370.

Berthelin, G. 1880. Mémoire sur les foraminiféres fossiles de l'Etage Albien de Moncley (Doubs). Mémoires de la Société Géologique de France, 31, 1-84.

Boukhary, M., Abd-Elshafi, E. \& Mattar, Y. 2011. Sanctus sinaicus n. gen., n. sp. (Foraminiferida, Amphisteginidae) from Late Eocene of Sinai, Egypt. Micropaleontology, 57, 537-542.

Brady, H.B. 1881. Notes on some of the reticularian Rhizopoda of the 'Challenger' Expedition, part 3. 1. Classification. 2. Further notes on new species. 3. Note on Biloculina mud. Quaternary Journal of Microscopical Science, new series, 21, 31-71.

Brady, H.B. 1884. Report on the foraminifera dredged by H.M.S. 'Challenger', during the years 1873-1876. Report of the Scientific Results of the Voyage of the H.M.S., Zoology, 9, 1-814.

Carsey, D.O. 1926. Foraminifera of the Cretaceous of central Texas. University of Texas Bureau of Economic Geology and Technology Bulletin, 2612, 1-56.

Chapman, F. 1916. Report on the foraminifera and ostracoda out of marine muds from soundings in the Ross Sea. 
Reports of Scientific Investigations, British Antarctic Expedition 1907-1909, Geology, 2, 53-80.

Cherif, O.H. \& El Deeb, W.Z. 1984. The Middle EoceneOligocene of the Northern Hafit Area, south of Al Ain City (United Arab Emirates). Geologie Méditerranéenne, 11, 207-217.

Culver, S.J. 2003. Benthic foraminifera across the Cretaceous-Tertiary (K-T) boundary: a review. Marine Micropaleontology, 47, 177-226.

Cushman, J.A. 1910. A monograph of the foraminifera of the North Pacific Ocean. Pt. 1, Astrorhizidae and Lituolidae. Bulletin of the United States National Museum, 71, 1-134.

Cushman, J.A. 1911. A monograph of the foraminifera of the North Pacific Ocean. Pt. 2, Textulariidae. Bulletin of the United States National Museum, 71, 1-108.

Cushman, J.A. 1925. An Eocene fauna from the Moctezuma River, Mexico. American Association of Petroleum Geology Bulletin, 9, 298-303.

Cushman, J.A. 1926. The foraminifera of the Velasco Shale of the Tampico Embayment. American Association of Petroleum Geology Bulletin, 10, 581-612.

Cushman, J.A. 1927. An outline of the re-classification of the Foraminifera. Contributions from the Cushman Laboratory for Foraminiferal Research, 3, 1-105.

Cushman, J.A. 1928. Foraminifera: their classification and economic use. Special Publication Cushman Laboratory for Foraminiferal Research, 1, 1-401.

Cushman, J.A. 1933. New foraminifera from the Upper Jackson Eocene of the southeastern coastal plain region of the United States. Contribution from the Cushman Laboratory for Foraminiferal Research, 9, 1-21.

Cushman, J.A. 1935. Fourteen new species of Foraminifera. Smithsonian Miscellaneous Collections, 91, 1-9.

Cushman, J.A. 1936. New genera and species of the families Verneuilinidae and Vulvulinidae and of the subfamily Virgulininae. Cushman Foundation for Foraminiferal Research, Special Publication, 6, 1-71.

Cushman, J.A. 1937. A monograph of the subfamily Virgulininae of the foraminiferal family Buliminidae. Special Publications Cushman Laboratory for Foraminiferal Research, 9, 1-228.

Cushman, J.A. 1949. The foraminiferal fauna of the Upper Cretaceous Arkadelphia marl of Arkansas. Geological Survey, Professional Paper 221-A. United States Government Printing Office, 1-31.

Defrance, J.L.M. 1824. Dictionnaire des Sciences Naturelles, 32. Moll-morf, Strasburg: E.G. Levrault.

Delage, Y. \& Hérouard, E. 1896. Truité de Zoologie Concréte, 1. La Cellule et les Protozoaires, Paris, Schleicher Fréres.

El-Dawy, M.H. 2001. Paleocene benthic foraminiferal biostratigraphy and paleobathymetry, El Sheikh Fadl and Ras Gharib, Eastern Desert, Egypt. Micropaleontology, 4, 23-46.

Ehrenberg, C.G. 1838. Über dem blossen Auge unsichtbare Kalkthierchen und Kieselthierchen als Hauptbestandtheile der Kreidegobirge. Bericht über die zu Bekanntmachung geeigneten Verhandlungen der Königlichen Preussischen Akademie der Wissenschaften zu Berlin, 1838, 192-200.
Fursenko, A.V. 1958. Osnovnye etapy razvitiya faun foraminifer v geologicheskom proshlom. Trudy Instituta Geologicheskikh Nauk. Akademiia Nauk Belorusskoi SSR. Minsk, 1, 10-29.

Futyan, A.I. 1976. Late Mesozoic and Early Cainozoic benthonic foraminifera from Jordan. Palaeontology, 19, 53-66.

Futyan, A.I. 1976. Late Mesozoic and Early Cainozoic benthonic foraminifera from Jordan. Palaeontology, 19, 53-66.

Gebhardt, H. 1997. Cenomanian to Turonian foraminifera from Ashaka (NE Nigeria): quantitative analysis and palaeoenvironmental interpretation. Cretaceous Research, 18, 17-36.

Hanslíková, E. 1972. Carpathian Upper Cretaceous foraminifera of Moravia (Turonian-Maastrichtian). Akademii, nakladatelstvi Československé akademie věd, Praha, 160 p.

Haq, B.U. \& Aubry, M.-P. 1978. Early Cenozoic calcareous nannoplankton biostratigraphy and palaeobiogeography of North Africa and the Middle East and Trans-Tethyan correlations. The Geology of Libya (1). 2nd Symposium on the Geology of Libya, Tripoli. 271-304.

Haque, A.F.M.M. 1956. The foraminifera of the Ranikot and the Laki of the Nammal Gorge, Salt Range, Pakistan. Pakistan Geological Survey Memoir, Palaeontologica Pakistanica, 1, 1-229.

Haynes, J. \& Nwabufo-Ene, K. 1998. Foraminifera from the Paleocene phosphate beds, Sokoto, Nigeria. Revista Española de Micropaleontologia, 30, 51-76.

Helal, S.A. 2002. Contribution to the Eocene benthic foraminifera and ostracoda of the Fayoum Depression, Egypt. Egyptian Journal Paleontology, 2, 105-155.

Heron-Allen, E. \& Earland, A. 1930. Some new foraminifera from the south Atlantic, 3, Miliammina, a new siliceous genus. Journal of the Royal Microscopical Society of London, 350, 38-45.

Hewaidy, A.A. 1994. Biostratigraphy and paleobathymetry of the Garra-Kurkur area, southeast Aswan. Egypt. Middle East Research Center, Ain Shams University, Earth Science Series, 8, 48-73.

Hewaidy, A.A. \& Al-Hitmi, H. 1993. Cretaceous-Early Eocene foraminifera from Dukhan oil field, west Qatar, Arabian Gulf (A-Suborders Textulariina, Involutinina and Miliolina). Al-Azhar Bulletin of Science, 4, 495-516.

Hewaidy, A.A. \& Strougo, A. 2001. Maastrichtian-lower Eocene benthic foraminiferal distribution and paleoecology of three outcrop sections in Farafra. Egyptian Journal Paleontology, 1, 1-22.

Hussein, A.I. 1997. Some agglutinated foraminifera from the Middle Eocene rocks of Egypt. Middle East Research Center, Ain Shams University, Earth Science Series, 11, 106-114.

Ismail, A.A. 1996. Paleocene time-marker benthonic foraminifera of Egypt. Middle East Research Center, Ain Shams University, Earth Science Series, 10, 198-213. 
Ismail, A.A. 2012. Late Cretaceous-Early Eocene benthic foraminifera from Esh El Mallaha area, Egypt. Revue de Paléobiologie, 31, 15-50.

Kaminski, M.A. 2004. The year 2000 classification of the agglutinated foraminifera. In: Bubík, M. \& Kaminski, M.A. (eds). Proceedings of the Sixth International Workshop on Agglutinated Foraminifera, London: Grzybowski Foundation Special Publication, 8, 237-255.

Kaminski, M.A. 2014. The year 2010 classification of the agglutinated foraminifera. Micropaleontology, 60, 89-108.

Kisel'man, E.N. 1972. Verkhnemelovye i Paleotsenovye foraminifery novogo roda Spiroplectinella. Trudy Sibirskogo Nauchno-Issledovatel 'skogo Instituta Geologii Geofiziki i Mineral'skogo Syr'ya (SNIIGGIMS) Ministerstva Geologii i Okhrany Nedr SSSR, 146, 134-140.

Lankester, E.R. 1885. Protozoa. In: Encyclopaedia Britannica, $19,9^{\text {th }}$ ed., $830-866$.

LeRoy, L.W. 1953. Biostratigraphy of Maqfi section, Egypt. Geological Society of America Memoir, 54, 1-73.

Loeblich, A.R. \& Tappan, H. 1961. The status of the foraminifera genera Ammodiscus Reuss and Involutina Terquem. Micropaleontology, 7, 189-192.

Loeblich, A.R. \& Tappan, H. 1985. Some new and redefined genera and families of agglutinated foraminifera. Journal of Foraminiferal Research, 15, 91-104.

Luger, P. 1988. Maastrichtian to Paleocene facies evolution and Cretaceous/Tertiary boundary in middle and southern Egypt. Revista Espaňola de Micropaleontologia, $n^{\circ}$ Extraordinario, 83-90.

Marsson, Th. 1878. Die Foraminiferen der Weissen Schreibkreide der Inseln Rügen. Mitteilugen des Naturwissenschaftlichen Vereins für Neu-Vorpommern und Rugen in Greifswald, 10, 115-196.

Mikhalevich, V.I. 1980. Sistematica i evolyutsiya foraminifera v svete novykh po ikh tsitologii i ul'trastrukture. Trudy Zoologicheskogo Instituta Academiya Nauk SSSR, 94, 42-61.

Mikhalevich, V.I. 1992. Makrosistema foraminifer [The macrosystem of the Foraminifera] Ph.D. Thesis St.-Pb., 1-43 (In Russian).

Mikhalevich, V.I. 1995. A new classification of the class Astrorhizata. Zoosystematica Rossica, 3, 161-174.

Mikhalevich, V.I. \& Kaminski, M.A. 2008. Revised systematics of the Schlumbergerinida (Phylum Foraminifera). In: Proceeding of the Seven International Workshop on Agglutinated Foraminifera (eds Kaminski, M.A. \& Coccioni, R.). Grzybowski Foundation, Special Publication, 13, 157-166.

Miklukho-Maklay, A.D. 1963. Verkhniy Paleozoy sredney Azii. Leningradskiy Universitet, Leningrad, 1-300.

Millett, F.W. 1898. Report on the Recent foraminifera of the Malay Archipelago collected by Mr. A. Durrand, E.R.M.S. 3. Journal of the Royal Microscopical Society, 607-614.

Moore, Jr., T.C., van Andel, T.H., Sancetta, C. \& Pisias, N. 1978. Cenozoic hiatuses in pelagic sediments. Micropaleontology, 24, 113-138.
Nakkady, S.E. 1950. A new foraminiferal fauna from the Esna Shale and Upper Cretaceous chalk of Egypt. Journal of Paleontology, 24, 675-692.

Nakkady, S.E. 1959. Biostratigraphy of the Um Elghanayem section, Egypt. Micropaleontology, 5, 453-472.

Nomura, R. \& Brohi, I.A. 1995. Benthic foraminiferal fauna during the time of the Indian-Asian contact, in southern Balochistan, Pakistan. Marine Micropaleontology, 24, 215-238.

Orbigny, A. d'. 1826. Tableau méthodique de la classe des Céphalopodes. Annales des Sciences Naturelles, Paris, 7, 245-314.

Orbigny, A. d'. 1839. Foraminifères. In: Ramon de la Sagra. Histoire Physique, Politique et Naturelle de l'ile de Cuba. Paris, Arthus Bertrand. 224 p.

Orbigny, A. d'. 1846. Foraminifères fossiles du Bassin Tertiare de Vienne (Austriche). Gide et Compagnie, Libraires-Editeurs, Paris, 1-303.

Ozsvárt, P. 2007. Middle and Late Eocene benthic foraminiferal fauna from the Hungarian Paleogene Basin: systematics and paleoecology. Geologica Pannonica, Special Publication, 2, 1-129.

Pawlowski, J., Holzmann, M. \& Tyszka, J. 2013. New supraordinal classification of Foraminifera: molecules meet morphology. Marine Micropaleontology, 100, 1-10; doi: 10.1016/j.marmicro.2013.04.002.

Phillips, J.D. 1971. Sea floor spreading and continental drift reconstructions around the Atlantic, part I: 266-276. Influence of the Continental drift on the distribution of the Tertiary benthic foraminifera in the Caribbean and Mediterranean regions. Symposium on the geology of Libya, University of Libya, Tripoli, 263-299.

Plummer, H.J. 1931. Some Cretaceous foraminifera in Texas. Bulletin University of Texas, 3101, 109-203.

Podobina, V.M. 1978. Sistematika i filogeniya Gaplofragmiidev. Tomsk, Tomsk Universitet.

Reuss, A.E. 1845. Die Versteinerungen der Böhmischen Kreideformation. Erste Abtheilung Stuttgart: E. Schweizerbart'sche Verlagsbuchhandlung und Druckerei, 1-58.

Reuss, A.E. 1851. Ober die fossilen foraminiferen und Entomostraceen der Septarienthone der Umgegend von Berlin. Zeitschrift der Deutschen Geologischen Gesellschaft, 3, 49-92.

Reuss, A.E. 1860. Die Foraminiferen der Westphälischen Kreideformation. Sitzungsberichte der K. Academie der Wissenschaften in Wien, MathematischNaturwissenschaftliche Classe, 40, 147-238.

Rosenbaum, G., Lister, G.S. \& Duboz, C. 2002. Relative motions of Africa, Iberia and Europe during Alpine orogeny. Tectonophysics, 359, 117-129.

Said, R. \& Kenawy, A. 1956. Upper Cretaceous and Lower Tertiary foraminifera from northern Sinai, Egypt. Micropaleontology, 2, 105-173.

Saidova, Kh.M. 1970. Planktonnye foraminifery iz rayona Kurilo-Kamchatskogo zheloba. Trudy Instituta Okeanologii, 86, 162-164.

Saidova, Kh.M. 1975. Bentosnye Foraminifery Tikhogo Okeana. Institut Okeanologii P. P. Shirshova. Akademiya Nauk SSSR, 875 p. 
Saidova, Kh.M. 1981. O sovremennom sosttoyanii sidtemy nadvidovykh taksonov Kaynozoyskikh bentosnykh foraminifer. Institut Okeanologii P. P. Shirshova. Akademiya Nauk SSSR, 73 p.

Sars, M. 1869. Fortsatte bemaerkninger over der dyriske livs udbredning i havets dybder. Forhandlinger $i$ Videnskasselskabet $i$ Kristiania, 1868, 246-275.

Sars, M. 1972. Undersøgelser over Hardangerfjordens Fauna. Forhandlinger $i$ Videnskasselskabet i Kristiania, 1871, 246-255.

Schwager, C. 1877. Quadro del proposto sistema di classificazione dei foraminiferi con guscio. Bollettino $R$. Comitato Geologico d'Italia, 8, 18-27.

Schwager, C. 1876. Saggio di una classificazione dei foraminiferi avuto riguardo alle loro famiglie naturali. Bolletino R. Comitato Geologico d'Italia, 7, 475-485.

Schwager, C. 1883. Die Foraminiferen aus dem Eocaenablegerungen der Libyschen wuste und Agyptens. Paleontographica, 30, 81-153.

Silvestri, A. 1903. Dimorfismo e nomenclatura d'una Spiroplecta. Altre notizie sulla struttura della Siphogenerina columellaris. Atti della Pontificia Academia Romana dei Nuovi Lincei, Roma, 56, 59-66.
Speijer, R.P. 1994. Extinction and recovery patterns in benthic foraminiferal paleocommunities across the Cretaceous/ Paleogene and Paleocene/Eocene boundaries. Geologica Ultraiectina, Universiteit Utrecht, 124, 1-191.

Sztrákos, K. 2000. Eocene foraminifers in the Adour Basin (Aquitaine, France): biostratigraphy and taxonomy. Revue de Micropaléontologie, 43, 71-172.

Sztrákos, K. 2005. Paleocene and lowest Eocene foraminifera from the north Pyrenean trough (Aquitaine, France). Revue de Micropaléontologie, 48, 175-236.

Widmark, J.G.V. \& Speijer, R.P. 1997. Benthic foraminiferal ecomarker species of the terminal Cretaceous (late Maastrichtian) deep-sea Tethys. Marine Micropaleontology, 31, 135-155.

Youssef, M. \& Taha, S. 2012. Biostratigraphy and paleoecology of Paleocene/Eocene $(\mathrm{P} / \mathrm{E})$ interval of some geological sections in Central Egypt. Arabian Journal of Geosciences, 2012, 1-23.

Zachos, J.C., Lohmann, K.C., Walker, J.C.G. \& Wise, S.W. 1993. Abrupt climate change and transient climates during the Paleogene: A marine perspective. Journal of Geology, 101, 191-213. 
